\title{
Primary endocrine carcinoma of the parotid salivary gland associated with a lung carcinoid: a possible new association
}

\author{
V EUSEBI, ${ }^{*}$ S PILERI, ${ }^{*}$ L USELLINI, $\dagger$ A GRASSIGLI, $\ddagger$ C CAPELLA $\dagger$ \\ From the *Istituto di Anatomia e Istologia Patologica, Università di Bologna, the †Centro di Diagnostica \\ Istopatologica, Istochimica ed Ultrastrutturale, Università di Pavia a Varese, and the $\ddagger$ Clinica Chirurgica $e$ \\ Terapia Chirurgica Generale, Università di Bologna, Italy
}

SUMMARY An endocrine carcinoma of the left parotid salivary gland in a 58-year-old woman is reported. The tumour displayed a large argyrophilic cell-component and at ultrastructural level endocrine-like granules (ELG) were evident.

As endocrine-paracrine cells are not normally present in the parotid, it is suggested that the endocrine elements may have been derived from an anomalous differentiation of the ductal epithelial stem cells.

A bronchial carcinoid, removed seven years previously, proved structurally, cytologically and histochemically different from the tumour of the parotid salivary gland. It is proposed that the occurrence of the two tumours might be an as yet undescribed association which is more than fortuitous.

Endocrine tumours of the parotid salivary gland are very rare. Nicod ${ }^{1}$ in 1958 described a typical argentaffin carcinoid of the left parotid gland, in a 51year-old woman. In 1963 an "undifferentiated" carcinoma of the parotid gland associated with Cushing's syndrome was reported; ${ }^{2}$ Koss et $a l^{3}$ described 14 cases of small cell (oat-cell) carcinoma of minor salivary gland origin; and lastly one case of neuroblastoma of the parotid gland, barely distinguishable from an undifferentiated carcinoma, has been described by Mackay et al in 1976.4

Here we report a case of an endocrine carcinoma of the parotid salivary gland, also studied ultrastructurally.

\section{Case report}

A 58-year-old female was admitted in November 1979 with a six-month history of a painful lump in the left parotid region. On physical examination a firm mass, fixed to the deep tissues, was found in the upper pole of the parotid gland. After excision the nodule was oval in shape and measured $1.5 \mathrm{~cm}$. across. It was firm in consistency, appeared greyish in colour with numerous small haemorrhagic foci on

Accepted for publication 11 November 1981 the cut surface and was surrounded by salivary gland tissue.

The past medical history of the patient revealed that seven years previously she underwent, in another hospital, a lower right lobectomy for a pulmonary "carcinoma" of a large bronchus. The patient had remained in good health until January 1979 when a subcutaneous nodule $1 \mathrm{~cm}$ across was excised from the right axilla. It was not in a lymph node and was regarded as a metastatic carcinoma consistent with mammary origin. Subsequently a right modified radical mastectomy was performed but no malignant changes could be found within the breast. At the time of writing the patient is alive and well 14 months after excision of the parotid nodule and no further signs of tumour recurrence have appeared. The radioimmunoassay for calcitonin performed a month after the parotid operation proved negative.

\section{Material and methods}

Sections from the tumour of the parotid gland together with the subcutaneous nodule and the pulmonary lesion were stained with haematoxylin and eosin (HE), alcian blue (AB) method at pH 2.5, periodic acid-Schiff (PAS) before and after diastase 
digestion, the Gomori method for reticulin, the Grimelius method for argyrophilic cells, the MassonFontana method for argentaffin cells, and the Congo red stain for amyloid.

An immunoperoxidase method ${ }^{5}$ using anti-actin antiserum (kindly supplied by Prof G Bussolati), antihuman ACTH antiserum (Wellcome), anticalcitonin antiserum (kindly supplied by Prof $E$ Solcia and JM Polak), anti-5-hydroxytryptamine antiserum (provided by $\operatorname{Dr} \mathrm{R}$ Buffa), antigastrin antiserum (provided by Prof E Solcia and Dr $\mathbf{J}$ Walsh), antiglucagon antiserum 4842 (provided by Prof E Solcia and Dr VLW Go), antibovine pancreatic peptide (BPP) antiserum (Lilly) and anti-metenkephalin antiserum (provided by Prof E Solcia and Dr JM Polak) were applied to the tumour of the parotid gland.

For electron microscopy, small blocks from the parotid nodule fixed in Carson's solution ${ }^{6}$ were postfixed in $1 \%$ osmium tetroxide, dehydrated and embedded in an Epon-Araldite mixture. Thin sections were stained with uranyl acetate and lead citrate and observed in a Zeiss EM 10 electron microscope.

\section{MOR PHOLOGY}

\section{Tumour of the parotid gland}

The tumour was surrounded by a thick fibrous capsule which separated it from normal parotid tissue. By studying serial sections, it was possible to establish that the tumour was not in an intraparotid or paraparotid lymph node. The neoplastic cells were clumped in nests, or in large sheets frequently separated by an amorphous hyaline material which stained faintly with Congo red. However, no green birefringence was observed by polarising microscopy. The neoplastic elements were round or spindle in shape displaying a finely eosinophilic granular cytoplasm. The overall superficial appearance of the neoplasm somewhat resembled that of a medullary carcinoma of the thyroid (Fig. 1). The nuclei varied from round to ovoid and exhibited prominent eosinophilic nucleoli. Mitoses were scanty.

Frequently, ductal structures were scattered through the tumour either isolated singly in the stroma or within the solid areas (Fig. 2). The cells lining ducts were cuboidal but occasionally appeared flattened (Fig. 3). Their round nuclei were centrally placed and displayed small nucleoli. The ductal lumina frequently contained eosinophilic PAS-positive material.

With the Grimelius method the majority of the cells appeared impregnated, to varying degrees, with the exception of the duct-lining cells (Fig. 4). The argyrophilic cells sometimes appeared singly placed at the base or wedged between the non-argyrophilic

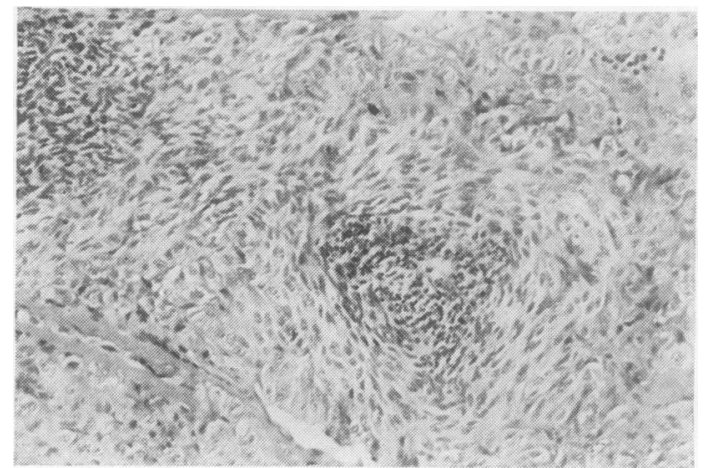

Fig. 1 The neoplastic elements appear spindle-shaped and form whorl-like structures. Haematoxylin and eosin $\times 100$.

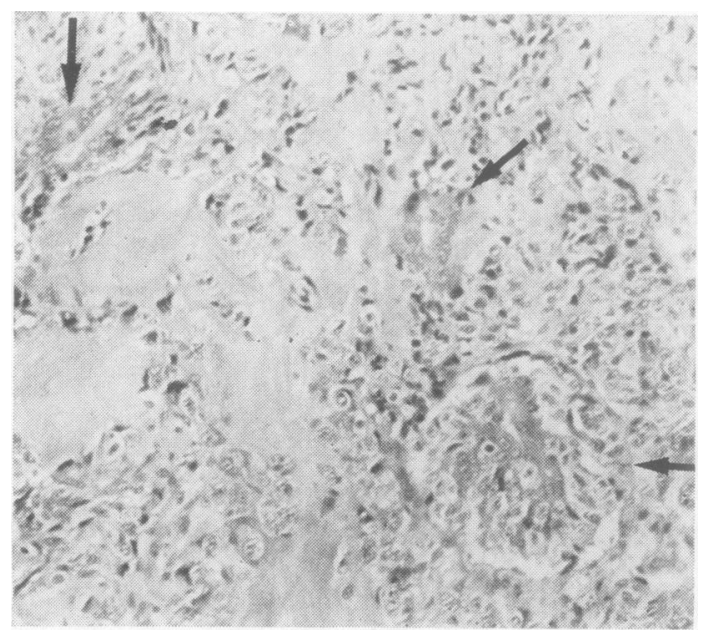

Fig. 2 The neoplastic cells surround ductal structures lined by cuboidal epithelium (arrows). Eosinophilic amorphous stroma is also evident. Haematoxylin and eosin $\times 100$.

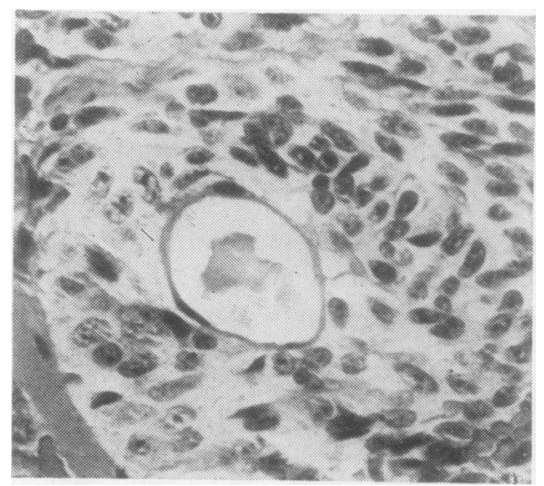

Fig. 3 A glandular space lined by fattened epithelium is evident in the centre of this neoplastic area.

Haematoxylin and eosin $\times 175$. 


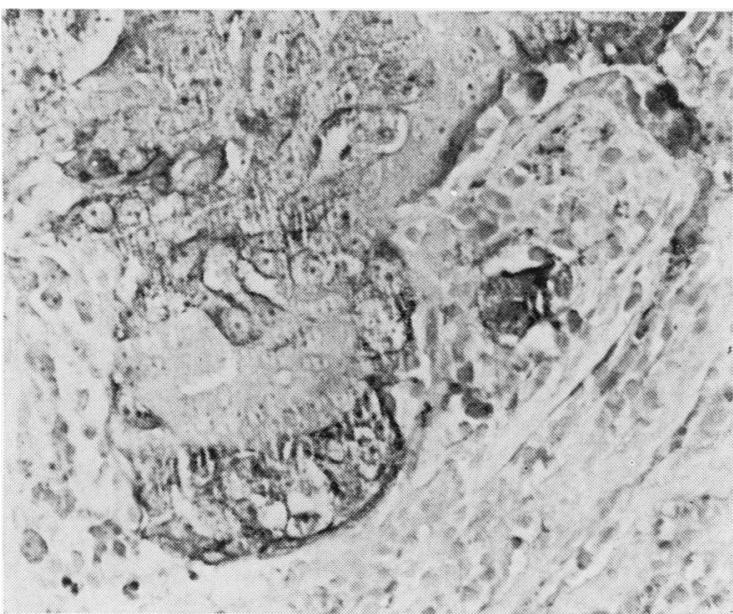

Fig. 4 The Grimelius-positive elements contrast with the cuboidal cells of the ducts which appear unstained. $\times 175$.

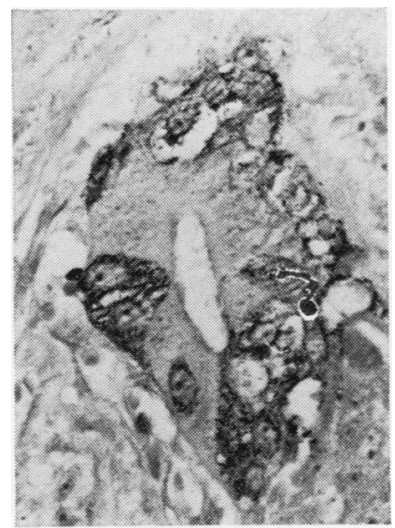

Fig. 5 Argyrophilic cells appear wedged between the non-argyrophilic elements of this duct. Grimelius $\times 200$.

elements of the ducts (Fig. 5). No Grimelius-positive cells could be found in the normal salivary tissue, nor did the tumour cells stain with the MassonFontana reaction.

With the immunoperoxidase methods tumour cells were negative with all the antisera used. Only scattered actin-positive elements were seen bordering the ducts of the normal parotid tissue.

On electron microscopic examination the neoplastic cells were arranged in nests and sheets or around ductal structures which contained secretory material within their lumina. The nests and sheets were composed of electron-translucent mediumsized polygonal or fusiform cells with ovoid or round nuclei (Fig. 6). The cell membranes were distinct and desmosome-like attachments were occasionally observed between adjacent cells. In about $70 \%$ of these

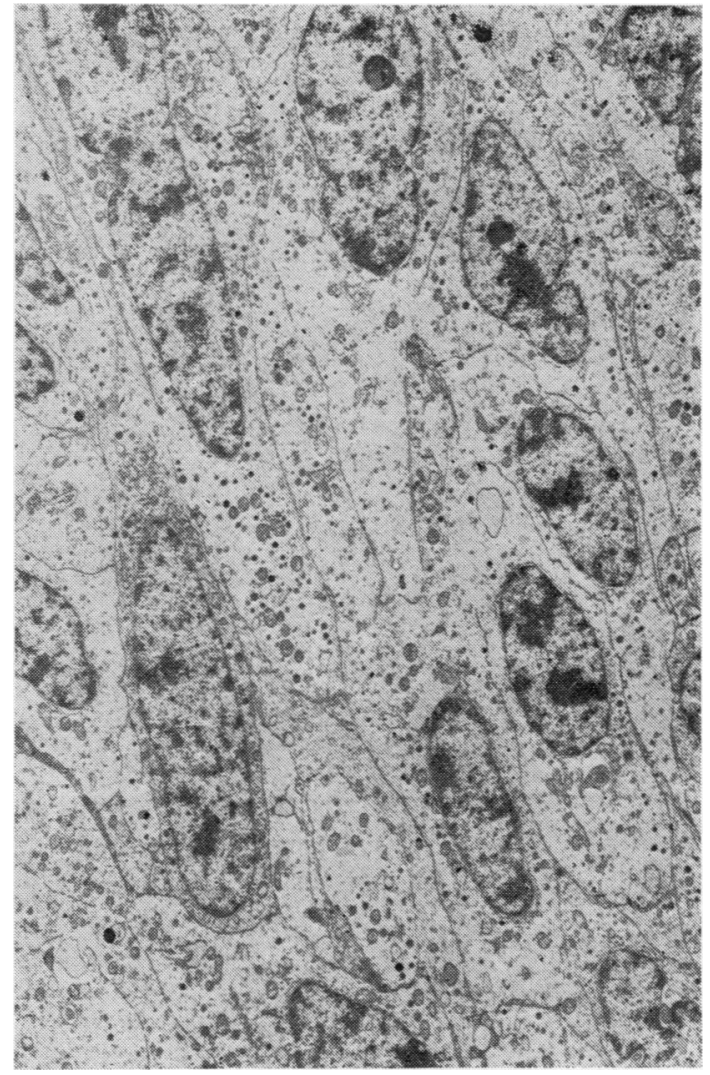

Fig. 6 Electron micrograph of a spindle cell area showing elongated endocrine-like cells containing moderate numbers of cytoplasmic dense-core granules. $\times 5600$.

cells endocrine-like granules (ELG) were seen. Their number varied from scanty in some cells to numerous in others. The granules were small (averaging $145 \mathrm{~nm}$ in diameter) and appeared uniform in size (Fig. 7). They displayed a dense core and a thin electronlucid halo below the limiting membrane. The ELG were mostly concentrated at the stromal pole of the cells. The granular endoplasmic reticulum component was variable in amount but usually not very prominent.

The cells forming the ductal structures varied from columnar to cuboidal and displayed numerous microvilli on their luminal surface. In the cytoplasm numerous large, irregularly outlined dense secretory granules were located immediately below the luminal surface. These granules closely resembled those found in the cells lining the normal human salivary gland ducts. ${ }^{7}$ Clumps of endocrine-like cells were interposed between the exocrine elements and an evident basal lamina (Fig. 8). 


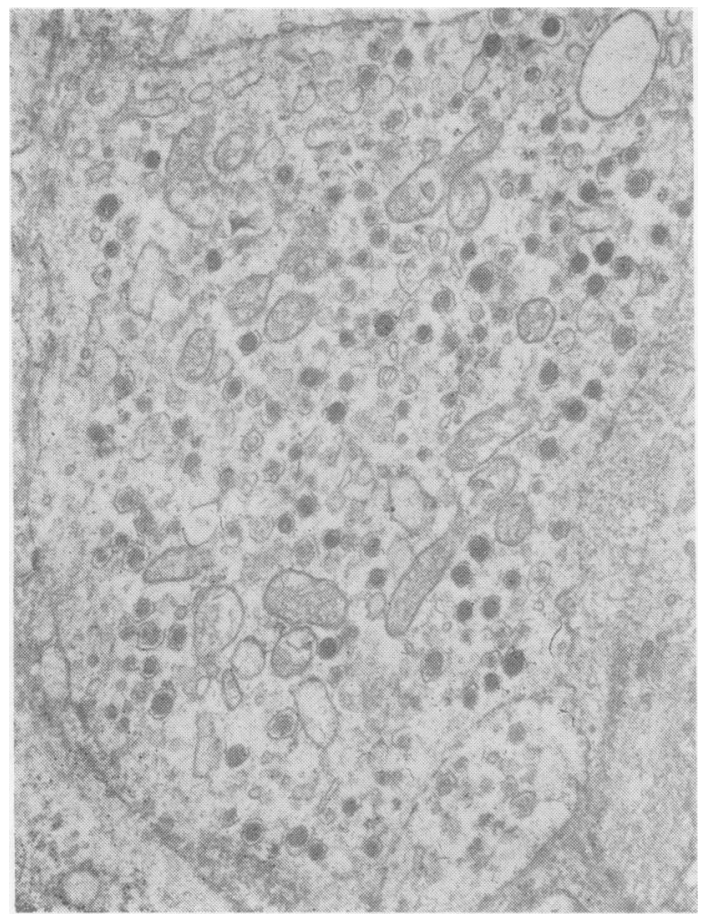

Fig. 7 Densely granulated endocrine-like cell containing numerous round osmiophilic granules with a thin halo separating the membrane from the core $\times 28000$.

In addition, a population of rather small round or ovoid cells with scarce cytoplasm containing abundant ribosomes, few mitochondria and occasional filaments, was observed. These cells, sparse in number and mostly located at the periphery of the ducts, were interpreted as immature ductal cells (stem cells). The stroma was abundant and contained fibroblasts, bundles of collagen and a dense network of irregularly orientated fibrils of varying thickness, which appeared very similar to the fibrils found in the adenoid cystic carcinomas of salivary gland ${ }^{8}$ and in a gastric carcinoid recently described by Wilander et al. ${ }^{9}$

\section{Skin nodule}

The skin nodule appeared structurally and cytologically identical to the tumour of the parotid gland, but no ductal structures were evident (Fig. 9). The Grimelius method was positive in most of the cells (Fig. 10). In the stroma amorphous eosinophilic material was also present which stained weakly with Congo red, but no dichroism could be seen.

Tumour of the lung

The pulmonary tumour slides were reviewed. The neoplastic proliferation consisted of solid alveolar

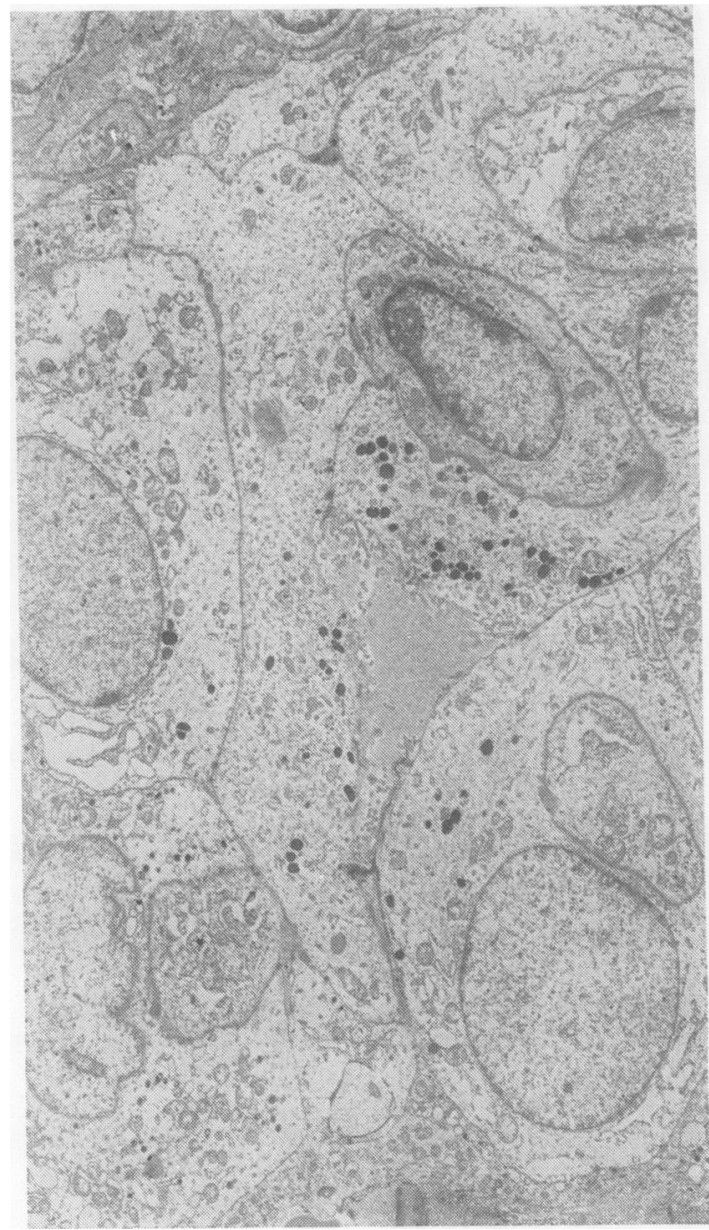

Fig. 8 Duct lined exocrine cells showing microvilli and large irregularly outlined, apical granules. These cells are directly surrounded by endocrine-like cells laying on a ductal basal lamina. $\times 5600$.

structures composed of uniform polygonal cells separated by thin fibrovascular septa. No ductal or glandular structures were observed. The neoplastic cells were small and displayed a clear or faintly acidophilic cytoplasm. The nuclei were round without nucleoli (Fig. 11). No cells appeared impregnated by the Grimelius method nor could AB or PASpositive material be seen. The stroma was negative with Congo red staining.

In view of these histological features the tumour was regarded as a pulmonary carcinoid with paraganglioid features. ${ }^{10}$

The two hilar lymph nodes available appeared reactive. 


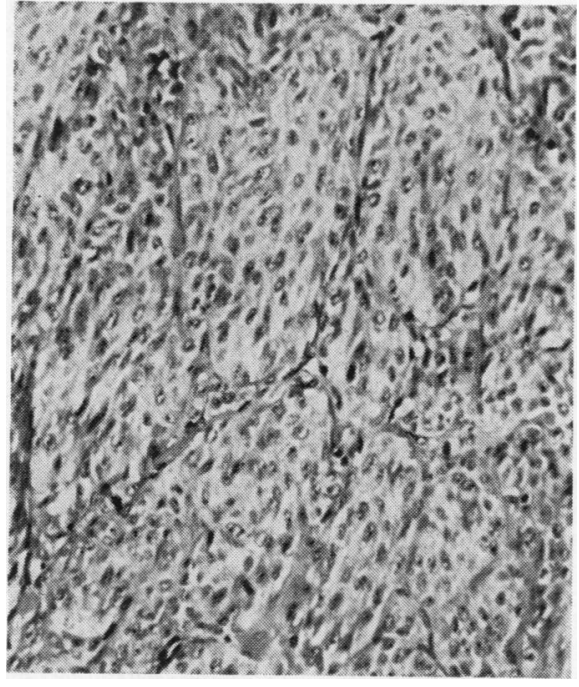

Fig. 9 The neoplastic elements of the axillary metastatic nodule appear spindle in shape as in the primary tumour. Haematoxylin and eosin $\times 100$.

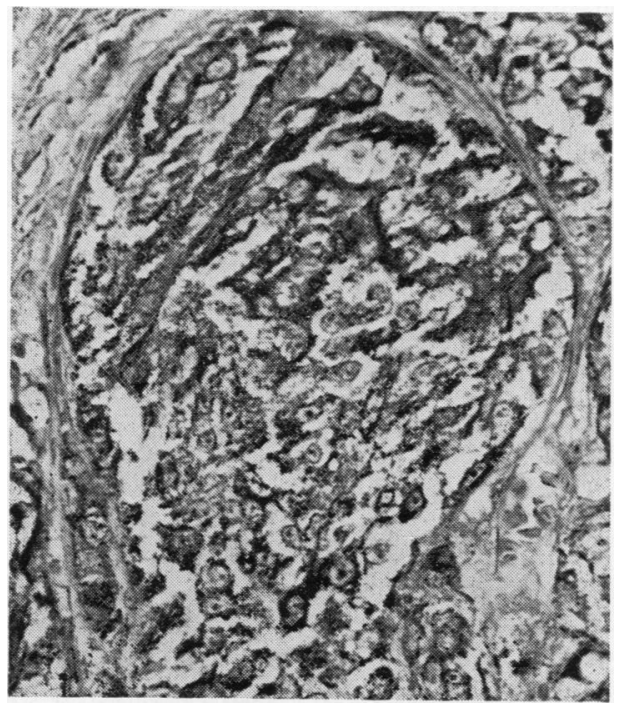

Fig. 10 Grimelius positive cells in the axillary metastatic tumour. $\times 175$.

\section{Discussion}

The tumour of the parotid gland was composed of round to spindle-shaped argyrophilic elements containing small dense-core granules at ultrastructural level.

Although the neoplastic cells were not positive with any of the antihormone sera used, the histo-

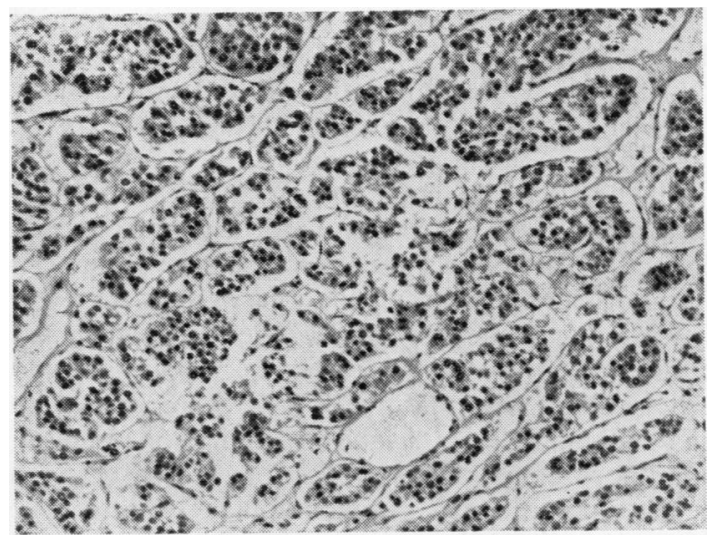

Fig. 11 The "paraganglioid" structure of the tumour of the lung is well evident. Haematoxylin and eosin $\times 75$.

chemical and ultrastructural data are consistent with the tumour cells having an endocrine nature; their granules being similar to those of $\mathbf{P}$ cells normally present in the human bronchial and gastric mucosa. ${ }^{11}$

Nests and sheets of argyrophil cells were in direct contact with ductal structures lined by exocrine cells which were ultrastructurally similar to those described in normal salivary gland ducts. ${ }^{7}$ Furthermore the endocrine-paracrine elements and the ductal cells were so often contained within the same basement membrane that a primary ductal origin seems very likely.

The pulmonary carcinoid exhibited a paraganglioid structure, with small non-argyrophil cells and scanty Congo red-negative stroma. It would appear therefore that the two tumours are structurally, cytologically and histochemically sufficiently different to suggest that they represent two independent endocrine tumours developing in the same patient.

Multiple endocrine adenomatosis is a well known syndrome with ever increasing associations, being described. ${ }^{12} 13$ It seems possible that the occurrence of a pulmonary carcinoid together with an endocrineparacrine tumour of the parotid gland might represent yet another unrecognised example of multiple endocrine tumours.

The skin nodule was practically synchronous with the tumour of the parotid gland, appearing both structurally and cytologically very similar except that it lacked residual glandular structures. The cells were also argyrophilic and hyaline Congo redpositive material was seen in the stroma. Therefore it seems justifiable to regard it as a probable metastasis from the tumour of the parotid gland rather than as secondary from the pulmonary carcinoid removed seven years previously. 
Moreover, in view of the aggressive behaviour of the parotid tumour as well as its structure and cytochemistry, we think that the designation of endocrine carcinoma is preferable to that of carcinoid.

The origin of the endocrine-paracrine tumours of the parotid gland is open to question. Carcinoids and endocrine carcinomas are generally believed to arise from cells of the diffuse endocrine system (DES) of Feyrter ${ }^{14}$ or APUD system of Pearse ${ }^{15}$ which are diffusely distributed in the digestive, respiratory and urinary tract. Argentaffin cells have been observed in dog submandibular glands ${ }^{16}$ and somatostatinimmunoreactive cells have more recently been detected in monkey submandibular glands. ${ }^{17}$ To date, no cells belonging to the DES have been identified in normal human salivary gland, and therefore the theory of origin from DES cells cannot yet be applied to parotid endocrine tumours.

An alternative hypothesis, elaborated elsewhere, ${ }^{18}$ is that the endocrine cells may represent an anomalous second line of differentiation derived from ductal stem cells. This view is supported by the coexistence, in the parotid tumour studied, of argyrophil cells, exocrine ductal cells as well as of undifferentiated elements which probably represent stem cells.

We think that the existence, albeit rare, of an endocrine carcinoma of the parotid salivary gland has to be taken into consideration and such a tumour distinguished from the spindle-cell (myoepithelial) carcinoma ${ }^{19}$ by the Grimelius method, electronmicroscopy and immunohistochemistry employing anti-actin antisera.

The authors wish to thank Prof JG Azzopardi for confirming the diagnosis. Acknowledgement is also due to Prof $\mathbf{R}$ Lattes for critically reading the manuscript.

\section{References}

${ }^{1}$ Nicod JL. Carcinoíde de la parotide. Bull Assoc Franc L'Etude Cancer 1958;45:214-22.

${ }^{2}$ Clinicopathological Conference. Cushing's syndrome associated with a parotid gland tumour. Am J Med 1963; 34:394-406.
${ }^{3}$ Koss LG, Spiro RH, Hajdu S. Small cell (oat cell) carcinoma of minor salivary gland origin. Cancer 1972; 30:737-41.

'Mackay B, Luna MA, Butler JJ. Adult neuroblastoma. Electron microscopic observation in nine cases. Cancer $1976 ; 37: 1334-51$.

${ }^{5}$ Sternberger LA. Immunocytochemistry. 2nd ed. New York: John Wiley, 1979.

${ }^{6}$ Carson FL, Martin JH, Lynn JA. Formalin fixation for electron microscopy: a re-evaluation. Am J Clin Pathol $1973 ; 49: 365-73$.

7 Tandler B. Ultrastructure of chronically inflamed human submandibular glands. Arch Pathol Lab Med 1977;101: 425-9.

8 Tandler B. Ultrastructure of adenoid cystic carcinoma of salivary gland origin. Lab Invest 1971;24:504-12.

${ }^{9}$ Wilander E, Westermark P, Grimelius L. Intracellular and extracellular fibrillar structures in gastroduodenal endocrine tumours. Ultrastruct Pathol 1980;1 :49-54.

${ }^{10}$ Capella C, Gabrielli M, Polak JM, Buffa R, Solcia E, Bordi C. Ultrastructural and histological study of 11 bronchial carcinoids. Virchows Archiv [Pathol Anat] 1979;381:313-29.

${ }^{11}$ Solcia E, Capella C, Buffa R, Usellini L, Frigerio B, Fontana $P$. Endocrine cells of the gastrointestinal tract and related tumours. In: Ioachim H. Pathobiology annual. Vol 9. New York: Raven Press, 1979:163-204.

12 Williams ED, Celestin IR. The association of bronchial carcinoid and pluriglandular adenomatosis. Thorax 1967;17:120-7.

${ }^{13}$ Newsome HH. Multiple endocrine adenomatosis. Surg Clin North Am 1974;54:387-93.

${ }^{14}$ Feyrter F. Über die peripheren endokrinen (parakrinen) Drüsen des Menschen. Wien: Mandrich, 1953.

${ }^{15}$ Pearse AGE. The cytochemistry and ultrastructure of polypeptide hormone producing cells of the APUD series and the embryologic, physiologic, and pathologic implications of the concept. J Histochem Cytochem 1969; 17:303-13.

${ }^{16}$ Godlowski ZZ, Calandra YC. Argentaffin cells in the submaxillary glands of dogs. Anat Record 1961 ;100:45-7.

17 Girod C, Dubois MP, Durand N. Immunocytochemical evidence for the presence of somatostatin-like immunoreactivity in scattered cells of the duct system of the submandibular glands in the monkey macaca irus Histochemistry 1980;69:137-43.

${ }^{18}$ Eusebi V, Azzopardi JG. Lobular endocrine neoplasia in fibroadenoma of the breast. Histopathology 1980;4: 413-28.

${ }^{19}$ Hamperl H. The myothelial (myoepithelial cells). Normal state; regressive changes; hyperplasia; tumours. Curr Top Pathol 1970;53:161-220.

Requests for reprints to: Dr V Eusebi, Istituto di Anatomia e Istologica Patologica, Policlinico S Orsola, Via Massarenti 9, 40100 Bologna, Italy. 